\title{
Activity of Proteolytic and Amylolytic Enzymes from Bacillus spp. Isolated from Shrimp Ponds
}

\author{
IT JAMILAH ${ }^{1,2}$, ANJA MERYANDINI $^{1}$, IMAN RUSMANA ${ }^{1 *}$, \\ ANTONIUS SUWANTO' ${ }^{1}$, AND NISA RACHMANIA MUBARIK ${ }^{1}$ \\ ${ }^{1}$ Department of Biology, Faculty of Mathematics and Natural Sciences, Institut Pertanian Bogor, \\ Darmaga Campus, Bogor 16680, Indonesia; \\ ${ }^{2}$ Department of Biology, Faculty of Mathematics and Natural Sciences, \\ Universitas Sumatera Utara, Jalan Prof A Sofyan No 3, Medan 20155, Indonesia
}

\begin{abstract}
Accumulation of feed excess in commercial shrimp ponds due to overfeeding could decrease water quality. Protein and starch are the primary components of shrimp feed. This study was conducted to characterize extracellular proteases and amylases of Bacillus spp. isolated from shrimp ponds. 72 proteolytic and amylolytic Bacillus spp. isolates were screened from shrimp ponds in Karawang, West Java. Ten isolates were selected for further characterization for their growth and ability to reduce total suspended solid generated from commercial shrimp feed. Bacillus sp. DA 5.2.3 and L5 showed excellent activity in reducing total suspended solid, by 37 and 30\% respectively. Protease and $\alpha$-amylase activities of Bacillus sp. DA 5.2.3 isolate were consistently higher than that of L5. Maximum total and specific protease activity of DA 5.2.3 isolate was $2.0 \mathrm{U} \mathrm{mL}^{-1}$ and $40.9 \mathrm{U} \mathrm{mg}^{-1}$ respectively, while the activities of the $\mathrm{L} 5$ isolate were $2.1 \mathrm{U} \mathrm{mL}^{-1}$ and $23.0 \mathrm{U} \mathrm{mg}^{-1}$ respectively. Based on its $16 \mathrm{~S}$ rRNA gene sequences, Bacillus sp. DA 5.2.3 showed 99\% similarity to Bacillus cereus XHJ-2-6. Bacillus sp. DA 5.2.3 could potentially be applied to maintain water quality by reducing total suspended solid in water columns of shrimp ponds.
\end{abstract}

Key words: Bacillus sp. DA 5.2.3, protease, $\alpha$-amylase, total suspended solid

Overfeeding in aquaculture system can influence water quality that hampers animal growth. Generally, $10 \%$ of feed remainds as waste in the water. A high load of feed in pond water can increase biological oxygen demand (BOD), bacterial population, and decrease dissolved oxygen (DO) content. It can also increase total suspended solid (TSS) in the water. Reduction of water quality has a bad influence on survival and growth of shrimps.

The used of bacterial probiotics in shrimp aquacultures has been studied and reported to have great impact on shrimp growth and survival. Some of these can maintain water quality by reducing the ammonia concentration in shrimp ponds, others can inhibit the growth of shrimp pathogens (Rengpipat et al. 1998; Vaseeharan and Ramasamy 2003; Decamp and Moriarty 2007), stimulate the immune system of the shrimp (Gullian et al. 2004) and increase digestive enzyme activity of the shrimps intestine (Ziaei-Nejad et al. 2006).

Bacillus spp. have derived great attention as a probiotic application in aquaculture in the last decade (Rengpipat $e t$ al. 1998; Vaseeharan and Ramasamy 2003; Decamp and Moriarty 2007). Many researchers reported their roles as biological control agents in shrimp ponds (Verschuere et al. 2000; Decamp and Moriarty 2007). Recently, Ochoa-Solano and Olmos-Soto (2006) studied the contribution of Bacillus as part of the functional feed to enhance shrimp feed quality. Several studies of potential protease from Bacillus cereus isolated from fish gut for converting fish-wastes have been reported. However, information about the role of Bacillus spp. to reduce shrimp feed wastes, was very limited. The group of Bacillus bacteria is well known as a producer of a large variety of extracellular protease and amylase. Therefore, this study attempted to identify potential proteolytic and amylolytic enzymes of Bacillus spp. isolated from shrimp

Corresponding author:, Phone/Fax: +62-251-8622833, E-mail: rusmana13@yahoo.com ponds for their potential application to maintain water quality in shrimp aquaculture.

\section{MATERIALS AND METHODS}

Sample Collection and Preparation. Nineteen samples of four different sample sources being soil, sediment and water and shrimp intestine were collected from shrimp ponds in Karawang, West Java, Indonesia. From samples of shrimp intestine were prepared by grinding and diluting in $0.85 \%(\mathrm{w} / \mathrm{v}) \mathrm{NaCl}$.

Isolation and Screening of Bacillus. Serial dilution of each sample in $0.85 \% \mathrm{NaCl}(\mathrm{w} / \mathrm{v})$ was follow by heating at $80{ }^{\circ} \mathrm{C}$ for $15 \mathrm{~min}$. Then, $100 \mathrm{~mL}$ aliquots solution was spread on half strength of solid seawater complete medium (SWC) (Atlas 1997) added with 1\% (w/v) skimmed milk. Cultures were incubated at room temperature 24-48 h. Proteolytic activity was shown by formation of clearing zones around colonies. Amylolytic activities of Bacillus spp. were screened by a similar method except SWC medium was mixed with $1 \%(\mathrm{w} / \mathrm{v})$ commercial cassava starch instead of glycerol was used as the carbon source. Clearing zones around the colonies were detected by iodine staining solution $\left(15 \mathrm{~g} \mathrm{~L}^{-1}\right.$ potassium iodide and $15 \mathrm{~g} \mathrm{~L}^{-1}$ iodine in distilled water). The proteolytic index (PI) or the amylolytic index (AI) value is the ratio of hydrolysis zone (clear zone) diameter $(\mathrm{cm})$ formed by a bacterium colony and its colony diameter $(\mathrm{cm})$.

Proteolytic and amylolytic activity positive colonies were isolated on solid SWC medium to give a pure culture. Confirmation of amylolytic and proteolytic activity of the pure culture isolates were conducted using similar methods as to mention above.

Growth Conditions of Selected Isolates. Selected high PI and AI value isolates were inoculated into $50 \mathrm{~mL} \mathrm{SWC} \mathrm{medium}$ in $250 \mathrm{~mL}$ flasks and then incubated on shaker $(120 \mathrm{rpm})$ at room temperature $\left(28^{\circ} \mathrm{C}\right)$ to get $10^{8} \mathrm{CFU} \mathrm{mL}^{-1}\left(\mathrm{OD}_{620 \mathrm{~nm}}=0.4\right)$. 
Then, $10 \mathrm{~mL}$ aliquots of cultures were inoculated into $100 \mathrm{~mL}$ of SF medium with $2.5 \%$ (w/v) salinity and $\mathrm{pH} 7.5$. Cell densities were determined at 24 and $48 \mathrm{~h}$.

Total Suspended Solid (TSS). Fifty $\mathrm{mL}$ of $1.2 \%(\mathrm{w} / \mathrm{v})$ shrimp feed (SF) medium ( $\mathrm{pH} 7.5$ ) was inoculated with $10 \mathrm{~mL}$ of bacteria with a concentration of $10^{8} \mathrm{CFU} \mathrm{mL}^{-1}$. Incubation was run at room temperature on a shaker (120 rpm) for $92 \mathrm{~h}$. TSS values were determined using filtration method.

Enzyme Production. Bacteria were grown in $1.2 \%(\mathrm{w} / \mathrm{v})$ SF medium adjusted to $\mathrm{pH}$ of 7.5 and incubated in a shaker at $120 \mathrm{rpm}$ at room temperature for $96 \mathrm{~h}$. Samples were taken at a $24 \mathrm{~h}$ time interval then centrifuged at $4500 \mathrm{x}$ g for 15 for min (Jouan C31) at $4{ }^{\circ} \mathrm{C}$. The clear supernatant was used as the crude enzyme preparation.

Protease Activity Assay. The substrate used for protease activity assay was $1 \%(\mathrm{w} / \mathrm{v})$ casein in $0.01 \mathrm{M}$ Tris-HCl buffer at $\mathrm{pH}$ 7.5. Tyrosine $0.37 \mathrm{mmoL} \mathrm{L}^{-1}$ was used for a standard. Each mixture enzyme reaction was incubated at room temperature for $10 \mathrm{~min}$ and the reaction was stopped by adding of $10 \%(\mathrm{w} / \mathrm{v})$ trichloro acetic acid (TCA). All tests were done in replicates. Protein concentration was measured using a colorimetric method (Bradford 1976). Bovine serum albumin was used as a standard. One unit of the enzyme activity (1U) is defined as the amount of enzyme needed to produce $1 \mu \mathrm{moL}$ tyrosine per min, while specific activity of an enzyme is a unit of enzyme activity divided by its protein concentration.

Amylase Activity Assay. Assay of $\alpha$-amylase activity was measure based on the colorimetric method (Benfeld 1955). Soluble starch at $1 \%(\mathrm{w} / \mathrm{v})$ was dissolved in $0.05 \mathrm{M}$ Tris- $\mathrm{HCl}$ buffer at $\mathrm{pH} 7.5$ and used as a substrate. One unit of enzyme activity $(1 \mathrm{U})$ is defined as an activity of the enzyme to produce $1 \mu \mathrm{moL}$ maltose per min.

Bacillus Identification. Identification of selected isolate was conducted based on morphology characterization. It was then confirmed with $16 \mathrm{~S}$ rRNA gene sequencing. DNA extraction was performed based on the CTAB (cetyl-trimethylammonium bromide) method. The 16S rRNA gene was amplified with polymerize chain reaction (PCR) machine (Gene Amp PCR system 2400, Perkin Elmer, Biosystem, USA) using a specific primer for bacteria (63f (5'CAGGCCTAACACATGCAAGTC) and 1387r (5'GGGCGGWGTGTACAAGGC) (Marchesi et al. 1998) (Research Biolab, Singapore). DNA was sequenced (Applied Biosystem, USA) and Blast analysis was conducted (NCBI: at http://www.ncbi.nlm.nih.gov).

\section{RESULTS}

Screening of Bacteria. There were 72 Bacillus spp. isolated from 19 samples taken from shrimp ponds in Karawang, West Java. All isolates assayed positive for proteolytic and/or amylolytic activities, were Gram positive and were rod shaped. Colony morphology of the isolates found generally were white-cream or cream in color, concentric or circle in shapes, entire and wave or ununiform in their margin morphology.

Isolation results showed that sediment was the most prolific source of Bacillus sp. compare to other sources, giving $36 \%$ followed by soil that gave up to $29 \%$ of the total isolates found. The lowest number of Bacillus spp. found was in the water samples (15\%), however it was higher than that in shrimp intestine samples. Most of the isolates found (90.3\%) had both proteolytic and amylolytic activities, which could be seen from clearing zone produced around colonies in half strength SWC-milk and SWC-starch medium (Table 1).

The proteolytic index (PI) and the amylolytic index (AI) of the isolates were varied. The PI value of the isolates isolated from soils were in the range of 1.2 and 6.9 while AI values were in the range of 1.5-5.6. The average of the PI and AI was 3.7 and 3.0 respectively. The L3, L5 and KAt 5.1 isolates had a high value of either proteolytic or amylolytic indexes. These isolates were selected for further study. The PI and AI values of the isolates isolated from pond sediment were in the range of 1.5-7.2 and 1.2-8.3 respectively. The average of PI and AI values were 3.4 and 3.0 respectively. $\mathrm{KPt}$ 7.1.1 and KPt 7.1.2b isolates had a high values of either PI or AI. The average of PI and AI values of the isolates isolated from water were 2.6 and 3.6 (Table 1). The isolates isolated from shrimp intestines mostly had higher values of $\mathrm{PI}$ and AI than isolates of other sources. The average values of PI and AI of the isolates were 5.8 (in the range of 2.7-18.8) and 5.3 (in the range of 1.4-7.8). The highest values of PI was performed by DA 2.2.1 isolate, but its AI value had a lower value than other isolates. The DA 5.2.3 isolate had high values of both PI and AI. This isolate was selected for further study. The DP 3.2.1 isolate had only proteolytic activity in contrast, others, such as DA 2.2.3, UA 1.2.1, UA 1.2.2 isolates only assayed positive for amylolytic activity.

Ten isolates were selected for further characterization based on their PI and AI values (Table 2). All isolates selected were Gram positive, rod-shaped, catalase positive and endospore-forming bacteria. When the isolates were grown in a solid SF medium, all were able to degrade starch of shrimp feed, denoted by formation of a clear zone. However, the clearing zones did not show proteolytic activity (unpublished data). In general, the AI value of the isolates growing in SWC starch medium were higher than of those grown in SF medium.

Growth of Selected Bacillus spp. All selected isolates grew well in SF medium (Fig 1a and 1b). However, they had different growth rates. The bacteria grew fast for the first $24 \mathrm{~h}$. The increase of the cell numbers was as high as $5 \log _{10}$ to 8 $\log \mathrm{CFU} \mathrm{mL}^{-1}$ and then the growth rate was reduced by further

Table 1 Isolated proteolytic and amylolytic Bacillus from shrimp ponds in Karawang, West Java

\begin{tabular}{|c|c|c|c|c|c|c|c|c|c|c|c|}
\hline \multirow{2}{*}{ Sources } & \multicolumn{3}{|c|}{ Number of } & \multirow[b]{2}{*}{ A } & \multirow{2}{*}{$\begin{array}{c}\text { Total of } \\
\text { isolate }\end{array}$} & \multirow{2}{*}{$\begin{array}{l}\% \text { of } \\
\text { isolate }\end{array}$} & \multicolumn{3}{|c|}{ Ranges of hydrolysis zone } & \multicolumn{2}{|c|}{ Average of hydrolysis zone } \\
\hline & Samples & $\mathrm{P}$ and $\mathrm{A}$ & $\mathrm{P}$ & & & & $\mathrm{PI} \pm \mathrm{S}$ & & $\mathrm{AI} \pm \mathrm{SE}$ & $\mathrm{PI} \pm \mathrm{SE}$ & $\mathrm{AI} \pm \mathrm{SE}$ \\
\hline Soil & 6 & 18 & 1 & 2 & 21 & 29 & $1.2 \pm 0.1$ to & $6.9 \pm 2.1$ & $1.5 \pm 0.1$ to $5.6 \pm 1.4$ & $3.7 \pm 0.3$ & $3.0 \pm 0.3$ \\
\hline Sediment & 4 & 26 & 0 & 0 & 26 & 36 & $1.5 \pm 0.0$ to & $7.2 \pm 0.1$ & $1.2 \pm 0.4$ to $8.3 \pm 1.0$ & $3.4 \pm 0.4$ & $3.0 \pm 0.3$ \\
\hline Water & 5 & 11 & 0 & 0 & 11 & 15 & $1.5 \pm 0.0$ to & $3.6 \pm 0.4$ & $2.0 \pm 0.5$ to $4.8 \pm 0.2$ & $2.6 \pm 0.2$ & $3.6 \pm 0.2$ \\
\hline Intestine & 4 & 10 & 3 & 3 & 14 & 19 & $2.8 \pm 0.1$ to & $18.8 \pm 0.3$ & $1.4 \pm 0.3$ to $7.8 \pm 0.3$ & $5.8 \pm 0.4$ & $5.3 \pm 0.6$ \\
\hline
\end{tabular}

P, proteolytic; A, amylolytic; PI, proteolytic index; AI, amylolytic index; SE, standard error. 
Table 2 Ten of 72 Bacillus spp. isolated from shrimp ponds

\begin{tabular}{llcl}
\hline \multirow{2}{*}{ Sources } & \multirow{2}{*}{ Isolate codes } & \multicolumn{2}{c}{ Hydrolysis index } \\
\cline { 3 - 4 } Soil & L3 & $3.7 \pm 0.4$ & $3.5 \pm 0.5$ \\
& L5 & $4.7 \pm 0.6$ & $3.5 \pm 0.3$ \\
\multirow{3}{*}{ Sediment } & KAt 5.1 & $3.3 \pm 0.2$ & $5.2 \pm 0.6$ \\
& KPt 7.1 .1 & $7.2 \pm 0.1$ & $2.5 \pm 0.0$ \\
& KPt 7.2 .1 & $6.6 \pm 0.9$ & $4.0 \pm 1.4$ \\
Water & bKAt 7.1 .1 & $2.3 \pm 0.1$ & $8.3 \pm 1.0$ \\
Intestine & NS & & \\
& DA 2.2 .1 & $18.8 \pm 0.3$ & $3.6 \pm 0.4$ \\
& DP 5.1 .1 & $4.2 \pm 0.6$ & $6.0 \pm 1.6$ \\
& DP 5.1 .2 & $4.0 \pm 0.3$ & $4.8 \pm 1.4$ \\
& DA 5.2 .3 & $4.7 \pm 0.3$ & $7.8 \pm 0.3$ \\
\hline
\end{tabular}

PI, proteolytic index; AI, amylolytic index; SE, standard error; NS, not selected.
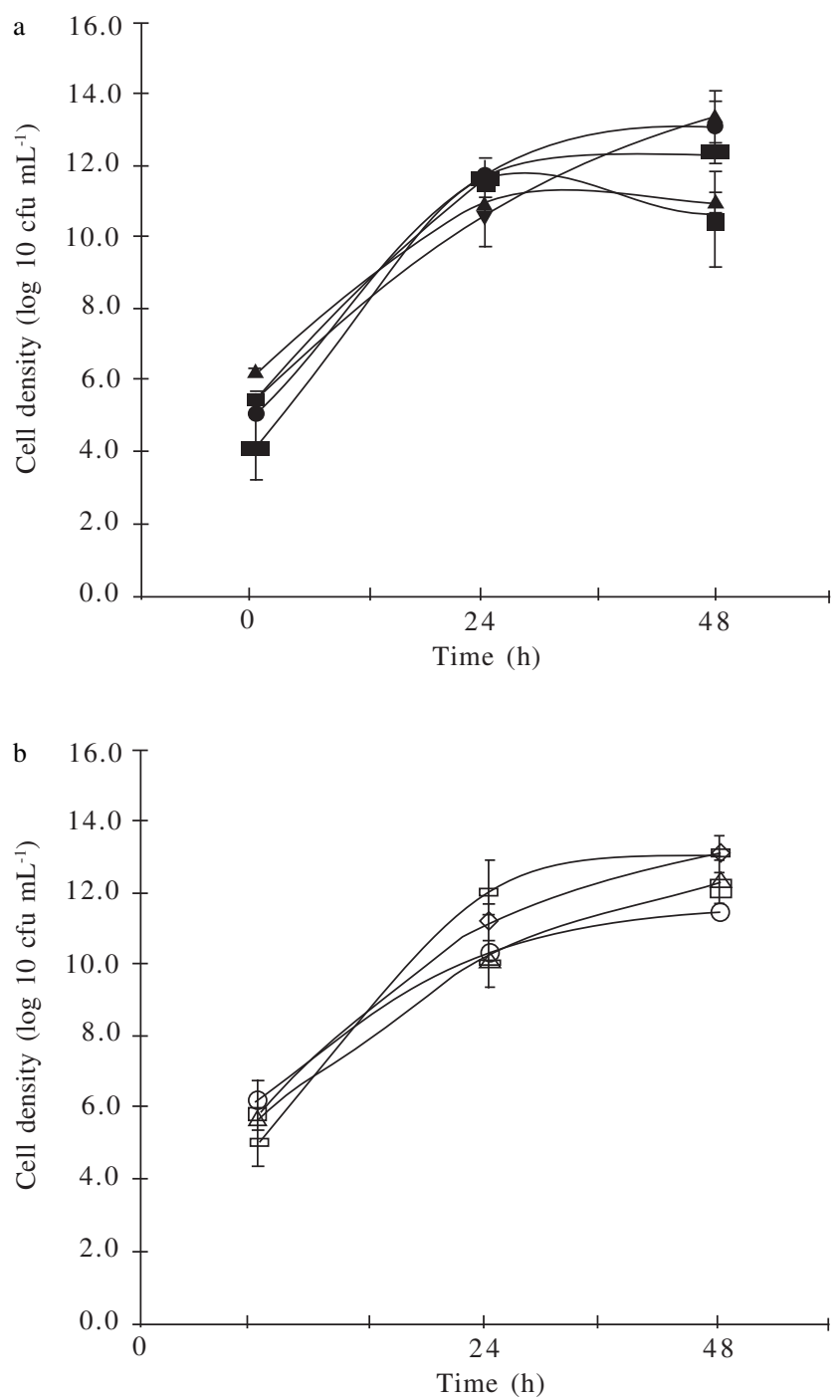

Fig 1 The growth of selected isolates of Bacillus spp. as probiotic candidates over incubation time in commercial shrimp feed medium a: $\bullet$, isolate KAt 7.1.2; $\boldsymbol{\square}$, isolate DP 5.1.1; $\boldsymbol{\Delta}$, isolate DP 5.1.2; $\square$, isolate DA 2.2.1; •, isolate DA 5.2.3. b : $\diamond$, isolate L3; 口, isolate L5; $\triangle$, isolate KAt 5.1 ; $\square$, isolate KPt 7.1.2b; o, isolate KPt 7.1.1.

incubation up to $48 \mathrm{~h}$. The increase of the cell was as much as 1 to $2 \log _{10} \mathrm{CFU} \mathrm{mL}^{-1}$. The data showed that a logarithmic phase was reached before $24 \mathrm{~h}$ of incubation, followed by a stationary phase after $48 \mathrm{~h}$ of incubation. The highest growth rate was performed by L5, DP 5.1.1 and DA 5.2.3 isolates. The number of cells increased up to $7 \log _{10} \mathrm{CFU} \mathrm{mL} \mathrm{m}^{-1}$.

Total Suspended Solid (TSS). Reduction of TSS was measured using $25 \mathrm{~mL} 1.2 \% \mathrm{SF}$ medium in $250 \mathrm{~mL}$ flask, incubated on shaker at room temperature $\left(28^{\circ} \mathrm{C}\right)$ for $92 \mathrm{~h}$. The highest reduction of TSS was perfomed by L5 and DA 5.2.3 isolates, which decreased TSS up to 36 and $30 \%$ respectively (Table 3).

Protease Activity. Bacillus sp. DA 5.2.3 and L5 were characterized of their protease activities in commercial SF as medium production. The DA 5.2.3 isolate showed higher proteolytic activity than the L5 isolate. The proteolytic activity of Bacillus sp. DA 5.2.3 was $2.0 \mathrm{U} \mathrm{mL}^{-1}$ higher than that of Bacillus sp. L5 (1.4 UmL $\left.\mathrm{Um}^{-1}\right)$. However, specific activity graphs of both isolates had a similar pattern. The highest specific activity of DA 5.2.3 and L5 isolates was $40.9 \mathrm{U} \mathrm{mg}^{-1}$ and 23.0 $\mathrm{U} \mathrm{mg}^{-1}$ respectively (Fig 2).

Amylase Activity. Total $\alpha$-amylase activity and its specific activity for DA 5.2.3 were also higher than that of the L5 isolate. The highest total $\alpha$-amylase activity of the DA 5.2.3 and the L5 isolate was reached in $24 \mathrm{~h}$ of incubation, which were $2.1 \mathrm{UmL}^{-1}$ and $0.5 \mathrm{UmL}^{-1}$ respectively (Fig 3). The activity of this enzyme subsequently decreased with the time of incubation. Specific activity of the DA 5.2.3 isolate was higher than that of the L5 isolate, which were $47.3 \mathrm{U} \mathrm{mg}^{-1}$ and $9.1 \mathrm{U} \mathrm{mg}^{-1}$ respectively.

Identification of Bacillus sp. DA 5.2.3. Morphology characterization of DA 5.2.3 isolate showed that this isolate

Table 3 Total suspended solid (TSS) of Bacillus spp. cultured in $1.2 \%$ commercial shrimp feed medium

\begin{tabular}{lcc}
\hline Isolates & $\begin{array}{c}\text { TSS } \\
\left(\mathrm{mg} \mathrm{mL}^{-1}\right)\end{array}$ & $\begin{array}{c}\text { TSS decreasing } \\
(\%)\end{array}$ \\
\hline L5 & 1640 & 36.9 \\
DA 5.2.3 & 1840 & 30.4 \\
DP 5.1.1 & 1880 & 27.6 \\
KPt 7.1.1 & 1880 & 27.6 \\
KAt 5.1 & 1920 & 26.0 \\
K.Pt 7.1.2b & 2000 & 23.0 \\
L3 & 2240 & 13.8 \\
KAt 7.1.2 & 2320 & 10.8 \\
DP 5.1.2 & 2400 & 7.7 \\
Control & 2600 & 0.0 \\
\hline
\end{tabular}

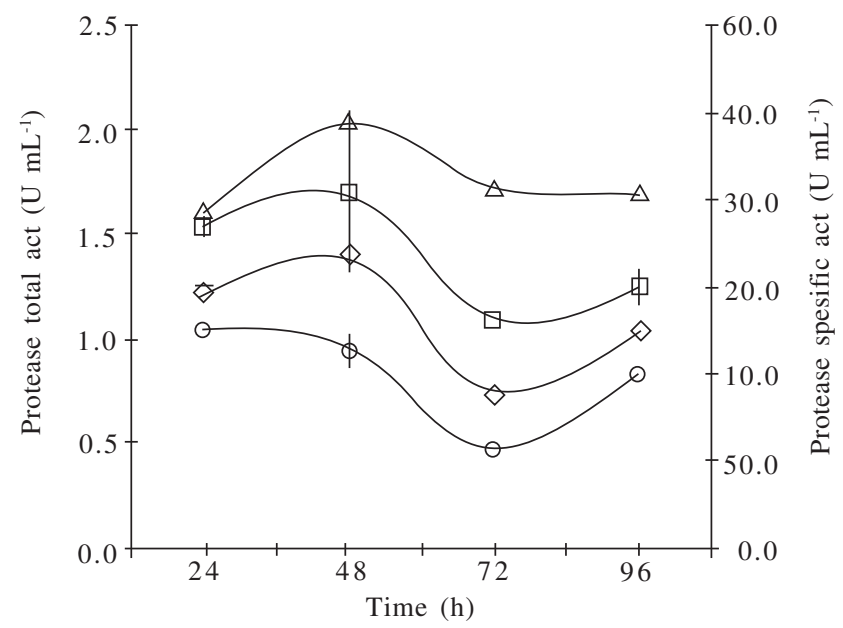

Fig 2 Protease activity of Bacillus sp. L5 and DA 5.2.3 over time production. $\triangle$, DA 5.2.3 total act; $\square$, DA 5.2.3 specific act; $\diamond$, L5 total act; 0 , L5 specific act. 


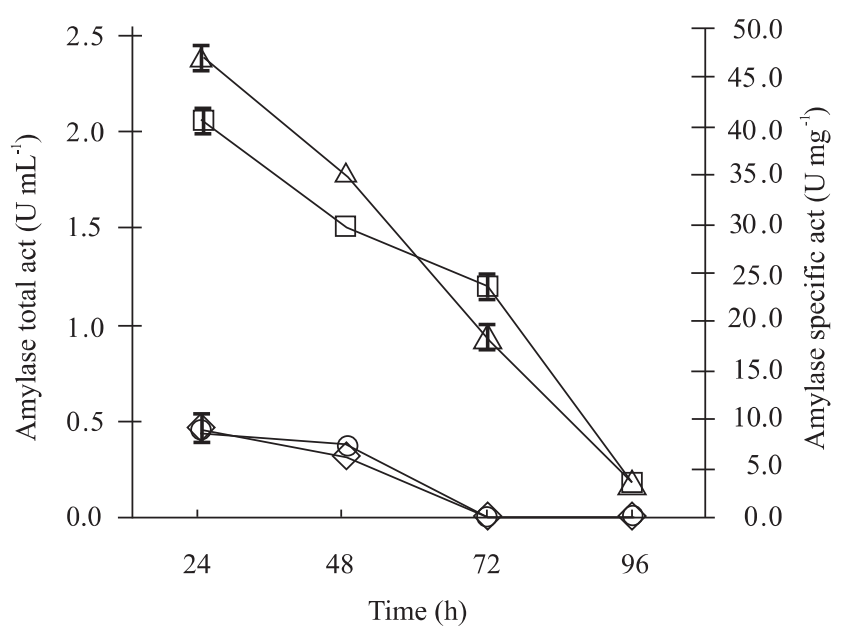

Figure 3 Alpha-amylase activity of Bacillus sp. L5 and DA 5.2.3 over time production. $\square$, DA 5.2.3 total act, $\triangle$, DA 5.2.3 specific act; $\bigcirc$, L5 total act; $\diamond$, L5 specific act. Bars indicate standard error.

was Gram positive, rod in shape, catalase positive and an endospore-forming bacterium. PCR amplification of its $16 \mathrm{~S}$ rDNA gene showed a $1.3 \mathrm{~kb}$ band on electrophoresis. Blast analysis of this gene sequences (NCBI) indicated that this isolate had the highest $16 \mathrm{~S}$ rDNA gene sequences similarity (99\%) with Bacillus cereus XHJ-2-6 (accession number: GQ 19959.1).

\section{DISCUSSION}

Higher numbers of Bacillus isolated from sediment may be expected because of sediment is at the bottom site of pond, and more nutrients are concentrated there. On the contrary, Bacillus isolated from shrimp digestive tract were the lowest in number. A low number bacteria was found in water samples compare to others site of ponds. Bacteria in aqueous environment can reach the animal digestive tract through drinking or swallowing of water by the animals. Lee et al. (2000) stated that one of factor for competency of probiotics was their ability to attach to intestine mucus. Therefore, only selected bacteria could survive in the intestine.

More than $90 \%$ isolates selected had both proteolytic and amylolytic activity. And most of Bacillus spp. isolates have more than one extracelullar enzymes. Bacillus spp. isolates taken from the shrimp digestive tract had the highest values of PI and AI. This could be due to a lot of nutrient being concentrated in intestine, so that only bacteria that have potential enzyme activity to degrade substrates could survive and could be more competitive in the intestine. Denkin and Nelson (1999) reported that the production of potease activity in fish digestive tract mucus of Vibrio anguilarum was higher than other media.

Selected isolates of Bacillus had the same growth pattern, and their logarithmic growth phase was reached at $24 \mathrm{~h}$ of incubation. Santos and Martins (2003) reported that logarithmic growth phase of Bacillus grown on $1 \%$ soluble starch and $1 \%$ maltose was reached at between 18 and $48 \mathrm{~h}$ of incubation.
The ability of the selected isolates to reduce total suspended solid values has potential application to maintain water quality in terms of total suspended solid reduction. Total suspended solid in shrimp-pond-water is mainly consists of shrimp feed excess which mostly contains protein, starch and lipid. Bacteria might degrade the feed particles into smaller ones using their extracellular enzymes. Proteases hydrolyze the smaller peptides and amino acids, facilitating partial absorption.

Protease and amylase activities of DA 5.2.3 isolate were higher than that of L5 isolate even though the PI values of the isolates were similar. This result implied that the PI value was not always correlated with enzyme activity in broth culture. In addition, the L5 isolate could decrease total suspended solid values by more than that of DA 5.2.3 isolate. This result might be arise because enzyme activities were measured using different substrates.

Alpha-amylase of the DA 5.2.3 isolate reached the maximum activities at the end of logarithmic growth phase, which was at $24 \mathrm{~h}$ from start of incubation. The activity was decreased sharply as the incubation time prolonged up to 48 , 72 or 96 h. Cordeiro et al. (2002) reported that a maximum $\alpha-$ amylase production of a thermophilic Bacillus sp. strain SMIA-2 was reached at $48 \mathrm{~h}$ or at the late stage of logarithmic growth phase in basal medium supplemented with $0.5 \%$ (w/ v) soluble starch. The activity was remained relatively constant up to $96 \mathrm{~h}$. Another study by Santos and Martin (2001) found that $\alpha$-amylase of moderately thermophilic Bacillus sp. was increased the production between 18-48 h of incubation in medium containing $1 \%(\mathrm{w} / \mathrm{v})$ maltose as the carbon sources. The variations of exoenzyme synthesis among these three isolates are could be expected because bacteria were grown in different substrates.

Protease activity produced by the L5 and the DA 5.2.3 isolates reached maximum activity at $48 \mathrm{~h}$ or at the beginning of the stationary growth phase. Then, it decreased gradually as the time of incubation was extended. The length incubation times of maximum protease production of by Bacillus strain was reported by some researchers, as being from 24 to $120 \mathrm{~h}$ from start of incubation (Chu et al. 1992; Mabrouk et al. 1999; Beg and Gupta 2003). Genckal and Tari (2006) stated that decreasing enzyme activity with prolonged time, could occur because of hydrolysis of the enzyme by proteases.

Based on all the data of this study, the DA 5.2.3 isolate has potential application to maintain water qualities in shrimp ponds. Based on molecular identification, this isolate was similar with Bacillus cereus XHJ-2-6. So far, there is no information about using this strain as probiotic in shrimp aquaculture. Therefore, it will be a great challenge to explore its characteristics further for probiotic development in aquaculture industry.

\section{ACKNOWLEDGEMENT}

This work was supported by a PhD studentship from the Directorate General of Higher Education, Department of Education, Indonesia to IJ. 


\section{REFERENCES}

Atlas RM. 1997. Hand Book of Microbiological Media. 2 $2^{\text {nd }}$ ed. Lawrence CP, editor. Boca Raton: CRC Pr.

Benfeld P. 1955. Amylases $\alpha$ and $\beta$ : Method Enzymol 1:149-58.

Beg QK, Gupta R. 2003. Purification and characterization of an oxidation stable, thiol-dependent serinealkaline protease from Bacillus mojavensis. Enzyme Microb Technol 32:294-304.

Bradford MM. 1976. A rapid and sensitive method for the quantities of protein utilizing the principle of protein-dye binding. Anal Biochem 72:248-54.

Chu IM, Lee C, Li TS. 1992. Production and degradation of alkaline protease in batch culture of Bacillus subtilis ATCC 14416. Enzyme Microb Technol 14:755-61.

Cordeiro CAM, Martin MLL, Luciano AB. 2002. Production and properties of $\alpha$-amylase from thermophilic Bacillus sp. Braz J Microbiol 33:57-61

Decamp O, Moriarty D. 2007. Aquaculture species profit from probiotics. Feed Mix 15:20-3.

Denkin SM, Nelson DR. 1999. Induction of protease activity in Vibrio anguillarum by gastro-intestinal mucus. Appl Environ Microbiol 65:3555-60.

Genckal, Tari C. 2006. Alkaline protease production from alkalophilic Bacillus sp. isolated from natural habitat. Enzyme Microb Technol 30:703-10.

Gullian M, Thompson F, Rodriguez J. 2004. Selection of probiotic bacteria and study of their immunostimulatory effect in Penaeus vannamei. Aquaculture 233:1-14.

Lee YK, Lim CY, Teng WL, Ouwehand AC, Tuomda EM, Salminen S. 2000. Quantitative approach in the study of adhesion of lactic acid bacteria to intestinal cell and their competition with Enterobacteria. Appl Environ Microbiol 66:3692-7.

Mabrouk SS, Hashem AM, El-Shayeb NMA, Ismail MS, Abdel-Fattah AF. 1999. Optimization of Alkaline protease productivity by Bacillus licheniformis ATCC 21415. Biores Technol 69:155-9.

Marchesi JR, Sato T, Weighman AJ, Martin TA, Fry JC, Hiom SJ, Wade WG. 1998. Design and evaluation of useful bacteriumspecific PCR primers that amplifygenes coding for bacterial $16 \mathrm{~S}$ rRNA. Appl Environ Microbiol 62:2501-7.

Rengpipat SS, Rukpratanpom S, Piyatitivorakul S, Menavetz P. 1998. Effect of probotic bacterium on black tiger shrimp Paneous monodon survival and and growth aquaculture Bacillus S11. Aquaculture 167:301-13.

Ochoa-Solano JL, Olmos-Soto J. 2006. The functional property of Bacillus for shrimp feeds. Food microbiol 23:519-25.

Santos EO, Martins MLL. 2003. Effect of the medium composition on formation of amylase by Bacillus sp. Braz Arch Biol Technol 46:129-34.

Vaseeharan B, Ramasamy P. 2003. Control of pathogenic Vibrio spp. by Bacillus subtilis BT 23 a possible probiotic treatment for black tiger shrimp Penaeus monodon. Lett Appl Microbiol 36: 83-7.

Verschuere L, Rombaut G, Sorgeloos P, Verstraete W. 2000. Probiotic bacteria as biological control agents in aquaculture. Microbiol Mol Biol Rev 64:655-71.

Ziaei-Nejad S, Rezaei MH, Takami GA, Lovett DL, Mirvaghefi AR, Shakouri M. 2006. The effect of Bacillus spp. bacteria used as probiotics on disgestive enzyme activity, survival and growth in the Indian white shrimp Fenneropenaeus indicus. Aquaculture 252:516-24. 